Florida International University FIU Digital Commons

FCE LTER Journal Articles

FCE LTER

2006

\title{
The contribution of leaching to the rapid release of nutrients and carbon in the early decay of wetland vegetation
}

\author{
Stephen E. Davis \\ Department of Wildlife and Fisheries Sciences, Texas A $-M$ University \\ Dan Childers \\ Department of Biological Sciences and Southeast Environmental Research Center, Florida International University, \\ childers@fiu.edu
}

Gregory B. Noe

U.S. Geological Survey

Follow this and additional works at: https://digitalcommons.fiu.edu/fce_lter_journal_articles

\section{Recommended Citation}

Davis, S.E., D.L. Childers, G.B. Noe. 2006. The contribution of leaching to the rapid release of nutrients and carbon in the early decay of wetland vegetation. Hydrobiologia 569(1): 87-97.

This material is based upon work supported by the National Science Foundation through the Florida Coastal Everglades Long-Term Ecological Research program under Cooperative Agreements \#DBI-0620409 and \#DEB-9910514. Any opinions, findings, conclusions, or recommendations expressed in the material are those of the author(s) and do not necessarily reflect the views of the National Science Foundation. This work is brought to you for free and open access by the FCE LTER at FIU Digital Commons. It has been accepted for inclusion in FCE LTER Journal Articles by an authorized administrator of FIU Digital Commons. For more information, please contact dcc@fiu.edu, jkrefft@fiu.edu. 
The Contribution of Leaching to the Rapid Release of Nutrients and Carbon in the Early

2 Decay of Wetland Vegetation

4 Stephen E. Davis, III ${ }^{1 \mathrm{a}}$, Daniel L. Childers ${ }^{2}$, and Gregory B. Noe ${ }^{3}$

$6{ }^{1}$ Department of Wildlife \& Fisheries Sciences, MS 2258, Texas A\&M University, College Station, TX 77843; 979-458-3475 (voice),979-845-4096 (fax), sedavis@tamu.edu

8

${ }^{2}$ Department of Biological Sciences \& SE Environmental Research Center, Florida International

10 University, Miami, FL 33199; 305-348-3101 (voice), 305-348-4096 (fax), childers@fiu.edu

$12{ }^{3}$ U.S. Geological Survey, 430 National Center, Reston, VA 20192; 703-648-5826 (voice), $703-$ 648-5484(fax),gnoe@usgs.gov

14

16 Keywords: leaf decomposition, organic carbon, nitrogen, phosphorus, North Inlet, Everglades

18 Note: This paper has not been submitted elsewhere in identical or similar form, nor will it be during the first three months after its submission to Hydrobiologia.

20

$22{ }^{a}$ Corresponding author

S.E. Davis et al. 


\section{Abstract}

Our goal was to quantify the coupled process of litter turnover and leaching as a source of nutrients and fixed carbon in oligotrophic, nutrient-limited wetlands. We conducted poisoned

4 and non-poisoned incubations of leaf material from four different perennial wetland plants (Eleocharis spp., Cladium jamaicense, Rhizophora mangle, and Spartina alterniflora) collected

6 from different oligotrophic freshwater and estuarine wetland settings. Total phosphorus (TP) release from the P-limited Everglades plant species (Eleocharis spp., C. jamaicense, and $R$.

8 mangle) was much lower than TP release by the salt marsh plant $S$. alterniflora from N-limited North Inlet (SC). For most species and sampling times, total organic carbon (TOC) and TP

10 leaching losses were much greater in poisoned than non-poisoned treatments, likely as a result of epiphytic microbial activity. Therefore, a substantial portion of the $\mathrm{C}$ and $\mathrm{P}$ leached from these

12 wetland plant species was bio-available to microbial communities. Even the microbes associated with S. alterniflora from N-limited North Inlet showed indications of P-limitation early in the

14 leaching process, as $\mathrm{P}$ was removed from the water column. Leaves of $R$. mangle released much more TOC per gram of litter than the other species, likely contributing to the greater waterborne [DOC] observed by others in the mangrove ecotone of Everglades National Park. Between the two freshwater Everglades plants, $C$. jamaicense leached nearly twice as much $\mathrm{P}$ than Eleocharis

18 spp. In scaling this to the landscape level, our observed leaching losses combined with higher litter production of $C$. jamaicense compared to Eleocharis spp. resulted in a substantially greater

20 P leaching from plant litter to the water column and epiphytic microbes. In conclusion, leaching of fresh plant litter can be an important autochthonous source of nutrients in freshwater and

22 estuarine wetland ecosystems. 


\section{Introduction}

2 Litter produced by deciduous and evergreen trees is the primary mechanism by which nutrients are returned to the soil (Swift et al., 1979). Herbaceous plants also shed leaves and

4 other aboveground parts, contributing to the recycling of nutrients and organic matter (Teal, 1962; Moran \& Hodson, 1989). This pool of litter represents a relatively large, labile reservoir

6 of organic matter to soil decomposer communities (Gosselink \& Kirby, 1985; Benner et al., 1986). Although resorption prior to leaf abscission can be an effective means of conserving vital

8 elements in many plant species, there is still a substantial outflow of organic and inorganic nutrients from trees and macrophytes via leaf senescence and decomposition (Tukey, 1970; Gosz

10 et al., 1973; Aerts, 1996; Killingbeck, 1996; Maie et al., 2006).

The initial leaching phase of wood and leaf litter decomposition typically lasts from a few

12 days to a few weeks, yet it is responsible for substantial loss of mass and release of materials such as carbon, nitrogen, and phosphorus to the environment (Ibrahima et al., 1995; Taylor \&

14 Bärlocher, 1996; Davis et al., 2003; Romero et al., 2005). Given that standing water or saturated soil conditions expedite this abiotic process (Tukey, 1970), the coupled process of litter

16 production and leaching may be an especially important autochthonous source of nutrients and fixed carbon in oligotrophic, nutrient-limited wetland systems. different perennial wetland plants (Eleocharis spp., Cladium jamaicense, Rhizophora mangle,

20 and Spartina alterniflora) collected from different oligotrophic freshwater and estuarine wetland settings. Our objectives were: 1) to quantify the time-dependent release of $\mathrm{C}, \mathrm{N}$, and $\mathrm{P}$ from

22 each of these species when immersed in water, 2) to evaluate the role of biological processes in governing these physically-driven losses of $\mathrm{C}, \mathrm{N}$, and $\mathrm{P}$ from each species, and 3) using 
published values on litter production in each of these wetland systems, we wanted to develop C,

$2 \mathrm{~N}$, and $\mathrm{P}$ budgets for each species associated with early (i.e. $<3$ weeks) decay. A common goal underlying these objectives was to identify links between oligotrophic status in wetland

4 ecosystems and leaching as a mechanism for the internal recycling of both limiting and nonlimiting elements.

6 Based on previous work by Davis et al. (2003), we hypothesized that leaching alone would be responsible for greater loss of materials than biotic processes (i.e. microbial

8 degradation) during the first three weeks of decomposition. However, we expected the biological contributions to litter decay to increase over this period of time, as microbial

10 colonization increased and leachable materials were exhausted. Lastly, given that these plants were all collected from oligotrophic, nutrient-limited systems, we anticipated that high resorption

12 efficiency would result in would result in relatively low leachable fractions of limiting elements (Feller et al., 1999; Richardson et al., 1999). In other words, we expected that the quantity of

14 phosphorus (normalized to dry mass of plant tissue) leached from phosphorus-limited plant tissue would be considerably less than phosphorus leached from a nitrogen-limited plant, and 16 vice versa.

\section{Materials and Methods}

Between August 2000 to July 2002, we conducted leaching experiments on leaf material

20 from four different wetland species. In 2000, we leached senesced, yellow leaves collected from an estuarine dwarf red mangrove (Rhizophora mangle) wetland along Taylor River, Everglades

22 National Park, Florida USA (Table 1). In 2001, we leached senesced tissue from two freshwater macrophytes (Cladium jamaicense leaves and Eleocharis spp. culms) collected in southeast 
Everglades National Park, just south of the C-111 canal (Table 1). Both Everglades wetlands

2 and associated plant communities are highly oligotrophic and limited by phosphorus availability (Davis, 1989; Koch \& Snedaker, 1997; Noe et al., 2001). Finally, in 2002, we leached senesced

4 leaf blades of Spartina alterniflora that were collected from North Inlet, South Carolina USA (Table 1). Studies of this pristine salt marsh ecosystem indicate that macrophyte productivity is

6 strongly limited by the availability of nitrogen, although soil microbial processes are phosphorus limited (Sundareshwar et al., 2003).

8 For all four species, only leaf material above the mean high water mark was collected, which we assumed had not been significantly leached already. Leaves were air-dried from the 10 time of collection to the initiation of the experiment - approximately 48 hours later. Leaves were weighed and incubated in $250 \mathrm{ml}$, clear, square, glass bottles containing $240 \mathrm{ml}$ of water

12 from each site. For all four species, we used approximately $1-4 \mathrm{~g}$ air-dried leaf material in each incubation bottle. Incubations lasted no longer than 21 days, as this is the timeframe needed to

14 fully capture the shift from abiotic to biotic contributions to decomposition (Davis et al., 2003). We assumed that ambient surface water from each wetland would provide the most realistic,

16 wetland-specific environment for the early decay of each species. However, prior to each set of incubations, we filtered $(\mathrm{GF} / \mathrm{F})$ the water to reduce variability in large particles $(>0.7 \mu \mathrm{m})$

18 between different water sources. The source water for each set of incubations was fresh (i.e., 0 $\%$ ), except for the S. alterniflora incubation, which was mesohaline (15\%; Table 2).

20 To help distinguish the contribution of leaching from microbial processes in the early phase ( $<3$ weeks) of leaf decomposition, we added a poison $\left(2 \mathrm{ml}\right.$ of a $1 \%$ solution of $\left.\mathrm{NaN}_{3}\right)$ to

22 half the bottles. The other half of the bottles received $2 \mathrm{ml}$ of de-ionized water. All the bottles from each study were incubated next to one another (spaced $2-5 \mathrm{~cm}$ apart from one another) in 
an outdoor setting in shallow $(<0.5 \mathrm{~m})$ water under ambient temperature and sunlight conditions.

2 All treatment combinations were conducted in triplicate for each set of incubations. In order to understand how leaching losses changed over time, we sacrificed three "poisoned" and three

4 "non-poisoned" bottles after 1, 2, 5, 10 and 21 days of incubation. Studies have shown that much of the leachable fraction is exhausted after 24 hours (Webster \& Benfield, 1986).

6 However, for some components, leaching can be detected for several days (Ibrahima et al., 1995).

8 During each sampling, leaves were removed from the bottles and water samples were collected. Water samples were stored in $125 \mathrm{ml}$, HDPE bottles at $4^{\circ} \mathrm{C}$ until analyzed for $\mathrm{C}, \mathrm{N}$,

10 and $\mathrm{P}$ content. All water nutrient analyses were conducted at the Southeast Environmental Research Center's laboratory at Florida International University. Samples were analyzed for

12 total phosphorus (TP) according to a modification of the dry ashing, acid-hydrolysis technique (Solorzano \& Sharp, 1980), for total nitrogen (TN) using an Antec 7000N total nitrogen

14 analyzer, and for total organic carbon (TOC) using a hot platinum catalyst, direct injection analyzer (Shimadzu model TOC-5000).

16 To ensure that changes in water nutrients were solely due to the leaves, control bottles containing only water or water + poison were incubated for the entire 21 -day length of each

18 experiment. Nutrient concentrations from the control bottles were compared with initial concentrations to determine changes in $\mathrm{C}, \mathrm{N}$, and $\mathrm{P}$ fractions associated with water column or

20 photochemical processes. Paired t-tests were used to determine significant differences between initial and final concentrations $(P<0.05)$. Since $\mathrm{NaN}_{3}$ was selected as the poison in this

22 experiment, TN concentrations were more than an order of magnitude higher in the bottles 
containing $\mathrm{NaN}_{3}$. Therefore, we are unable to report on the fluxes of $\mathrm{TN}$ in bottles containing

2 the poison.

Because we used air-dried leaf material, an accurate means of estimating initial oven-

4 dried mass was needed in order to normalize calculated releases of $\mathrm{C}, \mathrm{N}$, and $\mathrm{P}$. To accomplish this, we converted oven-dried mass to air-dried mass for each species (Table 1). These

6 conversions were generated from 25-30 individual leaves of each species that were weighed after being air-dried during the same period of time as the experimental leaves ( $\leq 48$ hours), then

8 oven-dried to a constant mass at $70^{\circ} \mathrm{C}$. The conversion for each species involved multiplying by the initial, air-dried mass in order to estimate initial dry mass for each experimental leaf. The changes in nutrients in bottles containing leaf material and poison were assumed to be the result of leaching. For those without poison, we assumed that both leaching and

12 biological processes were at work in governing $\mathrm{C}, \mathrm{N}$, and $\mathrm{P}$ dynamics. We calculated total releases from each incubation bottle as the change in the molar quantities of TOC, TN, and TP

14 from initial source water, normalized to the predicted initial dry mass of leaf material in each bottle per time of incubation (in moles $\mathrm{X}$ gdw leaf material ${ }^{-1}$ time $^{-1}$ ). We do not present data on

16 rates of $\mathrm{C}, \mathrm{N}$, and $\mathrm{P}$ release, but these values can be easily estimated by dividing the total release by the number of days incubated (i.e., 1 or 21 ).

We used analysis of variance (ANOVA) to determine the effect of time on early decay of leaf material, comparing the yield of $\mathrm{C}, \mathrm{N}$, and $\mathrm{P}$ leached from all species after 1 day of

20 incubation to total fluxes after 21 days of incubation. We also used ANOVA to determine the effect that the poison had on releases of $\mathrm{C}, \mathrm{N}$, and $\mathrm{P}$ in each species to discern the time-

22 dependence of biological contributions to these releases. Lastly, we used ANOVA to determine species effects on releases of each of these constituents over a three-week period of time. For 
each of these analyses, Tukey-Kramer post-hoc tests were used to determine differences between

2 treatment means of significant ANOVAs $(P<0.05)$. By doing these analyses and focusing on initial, 1-day releases and 21-day yield, we hoped to generate a better understanding the role of

4 microbes in governing the fate of leached $\mathrm{C}, \mathrm{N}$, and $\mathrm{P}$ for each species.

\section{Results}

All species released a significant amount of TOC, TN, and TP after just 1 day (Figures 1-

8 3), compared to control bottles (i.e., those without leaves) that showed no significant change in these constituents over each of the 3-week experiments (see Table 2 for initial concentrations of

10 TOC, TN, and TP in each water source). We also collected $\mathrm{C}, \mathrm{N}$, and $\mathrm{P}$ data from each set of incubations after 2, 5, and 10 days of incubation, but these data only followed the trends we

12 observed after 1 and 21 days. Therefore, we chose to omit these days from our discussion and focus on the time end-members of these experiments.

For all species and poison treatment combinations, 21-day total releases of TOC and TP were always significantly greater than 1-day total releases, indicating that a substantial pool of leachable materials still existed within the leaves after one day (ANOVA; $\mathrm{p}<0.0001$ ). However, the rate of release was highest in the first day for all species (ANOVA; $p<0.0001$ ). When comparing within species, $R$. mangle leaves released an order of magnitude more TOC than the other three species regardless of the addition of poison (ANOVA; $p<0.0001$ ).

20 From Day 1 to Day 21, the amount of TOC released by $R$. mangle jumped by more than ten-fold (Figure 1). The other species did not exhibit this same magnitude of trend for TOC release, as

22 the increases from Day 1 to Day 21 shown by C.jamaicense, Eleocharis spp., and S. alterniflora were each less than three-fold (Figure 1). For these same three species, the difference between 
poisoned and non-poisoned incubations was significant (poisoned $>$ non-poisoned) during both

2 days of sampling (Table 3), indicating a sustained biological effect on the early release of TOC. Rhizophora mangle leaves revealed a similar biological effect after 1 day of immersion.

4 However, we could not statistically differentiate poisoned releases of TOC from non-poisoned releases by Day 21 in the mangrove leaf incubations (Table 3, Figure 1).

6 The amount of TP leached from these four species was considerably less than the amount of TOC released, ranging from sub- $\mu$ mole levels of TP (e.g., all Everglades species after 1 day of

8 incubation) to as much as $13.5 \mu$ moles ${\mathrm{TP} \mathrm{gdw}^{-1}}^{-1}$ from S. alterniflora blades after 21 days. Overall, Spartina alterniflora blades released significantly more (by about an order of

10 magnitude) TP than leaf material from the three Everglades species (ANOVA; $\mathrm{p}<0.0001$ ), which were limited by $\mathrm{P}$ availability in their respective natural settings. Total phosphorus

12 leached from poisoned and non-poisoned incubations containing $R$. mangle leaves were not different after 1 day, but poisoned releases were more than twice those of non-poisoned

14 incubations after 21 days. All other species showed significantly higher releases of TP after 1 day in the presence of poison (Table 3, Figure 2). From Day 1 to Day 21, total release of TP by S. alterniflora blades increased, but the increases were most noticeable in the non-poisoned incubations, which more than doubled

18 (Figure 2). In fact, after 21 days, poisoned and non-poisoned releases of TP by S. alterniflora were not significantly different (Table 3). After 21 days of incubation, all three Everglades

20 species showed a significantly greater release of TP with poison (Table 3; Figure 2).

Release of TN could only be discerned in the non-poisoned incubations, as the $\mathrm{NaN}_{3}$

22 poison interfered with our ability to detect significant TN change. Non-poisoned releases of TN from Eleocharis spp. culms were significantly greater than those by $R$. mangle and $C$. 
jamaicense, but neither group could be distinguished from TN releases by S. alterniflora, the

2 species we assumed to be limited by $\mathrm{N}$ in its natural environment (ANOVA; $\mathrm{p}<0.005$; Figure 3). Incubations containing S. alterniflora leaf material showed little net change in TN levels

4 from Day 1 to Day 21, while the three Everglades species yielded more TN after 21 Days and showed similar trends in disparity between Day 1 and Day 21(Figure 3)

6

\section{Discussion}

As expected, we saw much lower release of phosphorus from leaves of species collected in P-limited wetlands (Everglades National Park) compared to a N-limited wetland (North Inlet,

10 SC). In fact, we estimate that the flux of P from leaching litter to a $1-\mathrm{m}^{2}$ patch of N-limited $S$. alterniflora ecosystem was up to two orders of magnitude greater than for the P-limited

12 Everglades species (Table 4). Further, these releases were substantially lower in the presence of biological processes that appeared to prevent the release of that $\mathrm{P}$ to the water column.

Although we did not measure the $\mathrm{P}$ content of the leaf tissue (or the biofilm layer that developed on it), we assumed that the difference between TP release in poisoned and non-

16 poisoned incubations was the result of microbes on the surface of the leaf mobilizing leached $\mathrm{P}$. Our measurements of water column TOC, TN, and TP reflected the initial concentrations of

18 these constituents plus the contribution of leached material and microbes suspended in the water column. Since we considered 'total' fractions in our analyses, declines in water column [TOC],

$20[\mathrm{TN}]$, and $[\mathrm{TP}]$ or differences between poisoned and non-poisoned incubations at a given time interval were assumed to be the result of respiration losses $(\mathrm{C}$ and $\mathrm{N})$ or incorporation into

22 microbial biomass on the leaf surface (C, N, and P). 
The disparity between poisoned and non-poisoned treatments in our study was greatest in

2 the two freshwater Everglades macrophytes (C. jamaiscense and Eleocharis spp.) and in $S$. alterniflora. Less TP leached to the water with live microbial communities, suggesting that a

4 significant portion of $\mathrm{P}$ leached from the plants in this study was labile and available to microbes. It is likely that the leached $\mathrm{P}$ boosted microbial activity in these treatments, as $\mathrm{P}$ not

6 only limits primary production, but also microbial processes in this wetland (Davis, 1989, Amador \& Jones, 1993).

The same may be true for S. alterniflora. Although $\mathrm{N}$ limits primary productivity in North Inlet (SC) salt marshes, Sundareshwar et al. (2003) showed that P limits soil microbial

10 respiration. This appeared to be the case early in our incubations when epiphytic microbial communities on dead leaf material reduced P leaching into the water column by half (Figure 2).

12 However, as time progressed, molar ratios of TN:TP in S. alterniflora incubations suggested a precipitous decline in $\mathrm{N}$ availability relative to $\mathrm{P}$-with $\mathrm{TN}$ :TP averaging 11 in source water and

14 less than 2 after 21 days in poisoned incubations (Figure 4). This trend was supported by TP and TN releases by $S$. alterniflora after 21 days.

16 That there was no difference between poisoned and non-poisoned release of TP after 21 days suggests that there was little demand for leached TP by epiphytic microbes at that time.

18 Further, no difference in the total amount of TN released by S. alterniflora in non-poisoned incubations after 1 day versus after 21 days suggests that $\mathrm{TN}$ releases were diminished by

20 epiphytic microbes sometime between Day 1 and 21. Based on the change in molar TN:TP over the duration of these incubations, it is likely that $\mathrm{N}$ became limiting to the microbial community

22 shortly after the first day of this set of incubations - when TN:TP averaged approximately 3 (Figure 4; Figure 6). All Everglades species showed a trend in water column TN:TP similar to $S$. 
alterniflora, but 21-day ratios were still over an order of magnitude higher, indicating P-

2 limitation throughout the duration of the leaf incubations (Figure 4).

Dwarfed Rhizophora mangle in the southern Everglades is widely thought to be limited

4 by P availability (Koch \& Snedaker, 1997; Feller et al., 1999). However, it may be that the lack of a biological effect on TP release after 1 day was the result of water column microbes in this

6 wetland being limited by the availability of labile organic carbon. We observed a two-fold reduction in TOC released from $R$. mangle leaves after one day when biological activity was

8 present (Figure 1). This corresponded with the lack of a 1-day difference in TP leaching between poisoned and non-poisoned incubations. After the large, 1-day pulse of TOC from these

10 leaves, biological activity likely shifted back to P-limitation, as evidenced by the significant difference between poisoned and non-poisoned releases of TP after 21 days and the lack of a

12 significant difference between poisoned and non-poisoned releases of TOC after this same period of time had elapsed (Figures 1 and 2).

14 Dead R. mangle leaves represent a potentially large source of leachable OC to the surrounding ecosystem (Table 4), supporting the observation that mangroves are a significant

16 source of DOM to Everglades estuarine ecosystems (Jaffé et al., 2004). Everglades mangrove ecosystems have higher surface water DOC concentrations, and more of this DOM is potentially

18 labile compared to upstream oligotrophic freshwater wetlands (Maie et al., 2005). However, freshwater oligotrophic wetlands of the Everglades can also be a net source of potentially labile 20 carbohydrates and proteinaceous material (Lu et al., 2003).

The different Everglades species exhibited a range of abiotic P leaching losses. The 22 maximum amount of TP leached from Eleocharis spp. in the first day in the poisoned bottles whereas S. alterniflora, C. jamaicense, and R. mangle leached TP at progressively slower rates 
through Day 21. The two freshwater Everglades species showed interesting contrasts in abiotic

2 P leaching. Although both C. jamaicense and Eleocharis spp. leached similar amounts of TP after 1 day in the poisoned bottles, after 21 days $C$. jamaicense leached twice as much TP

4 compared to Eleocharis spp., but this was a statistically insignificant difference. The greater inherent leachability of the $\mathrm{P}$ remaining in $C$. jamaicense litter after re-adsorption compared to

6 Eleocharis spp. is surprising given the lower concentration of $\mathrm{P}$ in dead C. jamaicense leaves than Eleocharis spp. culms (Rubio \& Childers, in review). In the end, the microbially mediated

8 release of TP from non-poisoned $C$. jamaicense was nearly identical to non-poisoned Eleocharis spp. culms and $R$. mangle leaves.

Leaching of nutrients from $C$. jamaicense litter results in larger ecosystem fluxes despite similar mass-specific leaching rates from litter as Eleocharis spp. The annual net primary

12 productivity of $C$. jamaicense is much greater than Eleocharis spp. in the Everglades, translating into a difference in litter production between these two herbaceous species (Daoust \& Childers,

14 2004; Childers et al., in review; Table 4). This results in a larger flux of $\mathrm{P}$ from soil to plant litter in the water column via translocation in $C$. jamaicense marsh $\left(7.49 \mathrm{mmol} \mathrm{P} \mathrm{m}^{-2} \mathrm{yr}^{-1}\right)$ compared to 16 Eleocharis spp. sloughs (1.10 $\mathrm{mmol} \mathrm{P} \mathrm{m}^{-2} \mathrm{yr}^{-1}$; Noe \& Childers, in review). The higher litter production of $C$. jamaicense compared to Eleocharis spp. also results in much larger fluxes of $\mathrm{P}$,

$18 \mathrm{~N}$, and $\mathrm{C}$ from this litter to the water column via leaching (Table 4). Using the non-poisoned leaching data from this study, we estimate the annual P flux from litter to the water column by

20 leaching to be 0.69 and $0.10 \mathrm{mmol} \mathrm{P} \mathrm{m}^{-2} \mathrm{yr}^{-1}$ for $C$. jamaicense and Eleocharis spp., respectively. Thus, 9\% of total litter P flux is leached into the water column for both species.

22 Phosphorus uptake from fresh litter by epiphytic microbes can be estimated by the difference in leaching fluxes between poisoned and non-poisoned treatments, equal to 1.55 and 
$0.07 \mathrm{mmol} \mathrm{P} \mathrm{m}^{-2} \mathrm{yr}^{-1}$ for $C$. jamaicense and Eleocharis spp., respectively, or $21 \%$ and $6 \%$ of total

2 litter $\mathrm{P}$ flux, respectively. This much larger flux of $\mathrm{P}$ to epiphytic microbes on $C$. jamaicense compared to Eleocharis spp. could have large feedbacks on ecosystem P cycling and transport.

4 Phosphorus in microbial biomass is more labile and likely has faster turnover rates than the refractory P remaining in plant litter, and could be more easily transported downstream through

6 long-term nutrient spiraling processes. The larger sum of $\mathrm{P}$ leaching fluxes from litter to both the water column and epiphytic microbes in $C$. jamaicense marsh $\left(2.23 \mathrm{mmol} \mathrm{P} \mathrm{m}^{-2} \mathrm{yr}^{-1}\right)$

8 compared to Eleocharis spp. sloughs $\left(0.16 \mathrm{mmol} \mathrm{P} \mathrm{m}^{-2} \mathrm{yr}^{-1}\right)$ represents a greater recycling of $\mathrm{P}$ from C. jamaicense plants to other ecosystem components in the soil and water column of this

10 oligotrophic, P-limited ecosystem. Finally, the increase in the P content of decomposing litter in the Everglades (Davis, 1991; Qualls \& Richardson, 2000) could be explained, in part, by 12 microbial mobilization of P leaching from litter and not solely uptake of water column P.

\section{Conclusions}

Abiotic leaching accounted for the greatest loss of C, N, and P from leaves of the four 16 species we considered. As expected, TP release from P-limited Everglades plant species was much lower than TP release by an N-limited North Inlet (SC) salt marsh plant. The presence of

18 microbial activity diminished the observed leaching yield, as normalized releases of $\mathrm{C}$ and $\mathrm{P}$ in non-poisoned incubations were usually significantly lower than in the poisoned incubations.

20 This suggests that that biological degradation of leaves in wetland settings may in fact be stimulated by the physical process of leaching that results in a rapid, labile energy source or

22 limiting elements such as phosphorus or nitrogen for microbial decomposers. Leaching of 
nutrients from plant litter to the water column can represent a large flux of nutrients in

2 oligotrophic ecosystems.

Long-term Ecological Research in the Florida Coastal Everglades seeks to understand the

4 role of wetland hydrology in driving materials exchange (carbon, nitrogen, phosphorus, suspended material, etc.) and productivity patterns at the land-sea interface. Our results suggest

6 that early leaf litter decay (i.e., leaching and microbial colonization) can contribute to local regulation of surface water quality. However, analogous studies should be conducted in the field

8 to ascertain the actual contribution of early macrophyte decay to spatial and temporal patterns in wetland ecosystem function. Further, studies such as these should also consider gradients of

10 ecosystem fertility and trophic status to fully understand the interactions between biological and physical processes in the early decay of wetland plant tissue.

\section{Acknowledgements}

14 We thank Damon Rondeau and the Southeast Environmental Research Center for analytical support. Jenny Davis, Luz Romero, and Alejandro Gaviria provided much-needed field and lab

16 support in completing these experiments. This work was supported in part by a 2002 Visiting Scientist award to SED from the Belle Baruch Institute at the University of South Carolina and is

18 SERC contribution \# XXX. This material is based upon work supported by the National Science Foundation to the Florida Coastal Everglades LTER Program (Grant No. 9910514), the

20 Everglades Priority Ecosystem Science Initiative of the U.S. Geological Survey, and the National Research Program of the U.S. Geological Survey. 


\section{List of References}

Amador, J.A. \& R.D. Jones. 1993. Nutrient limitations on microbial respiration in peat soils

4 with different total phosphorus content. Soil Biology and Biochemistry. 25(6): 793-801.

6 Aerts, R. 1996. Nutrient resorption from senescing leaves of perennials: are there general patterns? Journal of Ecology. 84:597-608.

Benner, R., E.R. Peele, \& R.E. Hodson. 1986. Microbial utilization of dissolved

10 organic matter from leaves of the red mangrove, Rhizophora mangle, in the Fresh Creek Estuary, Bahamas. Estuarine, Coastal and Shelf Science. 23:607-619.

Childers, D.L., D. Iwaniec, D. Rondeau, G. Rubio, E. Verdon, \& C. Madden. In review. Primary

14 productivity in Everglades marshes demonstrates the sensitivity of oligotrophic ecosystems to environmental drivers. Aquatic Botany.

16

Daoust, R.J. \& D.L.Childers, 2004. Ecological effects of low-level phosphorus additions on two 18 plant communities in a neotropical freshwater wetland ecosystem. Oecologia. 141:672-686.

20 Davis, S.E., C. Coronado-Molina, D.L. Childers, \& J.W. Day, Jr. 2003. Temporally dependent $\mathrm{C}, \mathrm{N}$, and $\mathrm{P}$ dynamics associated with the decay of Rhizophora mangle L. leaf litter in

22 oligotrophic mangrove wetlands of the southern Everglades. Aquatic Botany. 75:199-215. 
Davis, S. M. 1989. Sawgrass and cattail production in relation to nutrient supply in the

2 Everglades. In R. R. S. and J. W. Gibbons (Eds.), Freshwater Wetlands and Wildlife. pp. 325341. U. S. Department of Energy. Charleston, S. C.

4

Davis, S.M. 1991. Growth, decomposition, and nutrient retention in Cladium jamaicense Crantz 6 and Typha domingensis Pers. in the Florida Everglades. Aquatic Botany 40: 203-224.

8 Feller, I. C., D. Whigham, J. O’Neill, \& K. McKee. 1999. Effects of nutrient enrichment on within-stand cycling in a mangrove forest. Ecology. 80(7):2193-2205.

10

Gosselink, J.G. \& C.J. Kirby. 1974. Decomposition of salt marsh grass, Spartina alterniflora

12 Loisel. Limnology and Oceanography. 19(5):825-832.

14 Gosz, J.R., G.E. Likens, \& F.H. Borman. 1973. Nutrient release from decoposing leaf and branch litter in the Hubbard Brook Forest, New Hampshire. Ecological Monographs. 43:17316191.

18 Ibrahima, A., R. Joffre, \& D. Gillon. 1995. Changes in leaf litter during the initial leaching phase: An experiment on the leaf litter of Mediterranean species. Soil Biology and Biochemistry. $20 \quad 27(7): 931-939$. 
Jaffé, R., J.N. Boyer, X. Lu, N. Maie, C. Yang, N.M. Scully, \& S. Mock. 2004. Source

2 characterization of dissolved organic matter in a subtropical mangrove-dominated estuary by fluorescence analysis. Marine Chemistry. 84:195-210.

4

Killingbeck, K. T. 1996. Nutrients in senesced leaves: keys to the search for potential resorption 6 and resorption proficiency. Ecology. 77(6):1716-1727.

8 Koch, M. S. \& S. C. Snedaker. 1997. Factors influencing Rhizophora mangle L. seedling development in Everglades carbonate soils. Aquatic Botany. 59:87-98.

10

Lu, X., D.L. Childers, J.V. Hanna, N. Maie, \& R. Jaffé. 2003. Molecular characterization of

12 dissolved organic matter in freshwater wetlands of the Florida Everglades. Water Research. 37:2599-2606.

14

Maie, N., C. Yang, T. Miyoshi, K. Parish, \& R. Jaffe. 2005. Chemical characteristics of

16 dissolved organic matter in an oligotrophic subtropical wetland/estuarine ecosystem. Limnology and Oceanography. 50:23-35.

18

Morris, J.T. \& B. Haskin. 1990. A 5-yr record of aerial primary production and stand

20 characteristics of Spartina alterniflora. Ecology 71:2209-2217.

22 Noe, G.B., D.L. Childers, \& R.D. Jones. 2001. Phosphorus biogeochemistry and the impact of phosphorus enrichment: Why is the Everglades so unique? Ecosystems. 4:603-624. 
2 Noe, G.B. \& D.L. Childers. In review. Phosphorus budgets in Everglades wetland ecosystems: The effects of nutrient enrichment. Ecosystems.

4

Qualls, R.G. \& C.J. Richardson. 2000. P enrichment affects litter decomposition,

6 immobilization, and soil microbial P in wetland mesocosms. Soil Science Society of America Journal. 64:799-808.

8

Richardson, C.J., G. Ferrell, \& P. Vaithiyanthan. 1999. Nutrient effects on stand structure,

10 resorption efficiency, and secondary compounds in Everglades sawgrass. Ecology. 80(7):21822192.

12

Rivera-Monroy, V.H., S. Ewe, R.R. Twilley, C. Coronado-Molina, E. Castaneda, E., \& T.J.

14 Grahl. In preparation. Scrub mangrove forest growth patterns and above-belowground productivity in Taylor River, Everglades National Park, Florida, USA.

16

Romero, L.M., T.J. Smith, \& J.W. Fourqurean. 2005. Changes in mass and nutrient content of 18 wood during decomposition in a south Florida mangrove forest. Journal of Ecology. 93:618631.

Rubio, G.A. \& D.L. Childers. In Review. Decomposition of Cladium jamaicense, Eleocharis 22 sp., and Juncus roemerianus in the estuarine ecotones of the Florida Everglades. Estuaries. 
Solorzano, L, \& J, H, Sharp. 1980. Determination of total dissolved phosphorus and particulate

2 phosphorus in natural waters. Limnology and Oceanography. 25(4):754-758.

4 Sundareshwar, P.V., J.T. Morris, E.K. Koepfler, \& B. Fornwalt. 2003. Phosphorus limitation of coastal ecosystem processes. Science. 299:563-565.

6

Swift, M.J., O.W. Heal, \& J.M. Anderson. 1979. Decomposition in Terrestrial Ecosystems.

8 Blackwell Scientific, Oxford, UK.

10 Taylor, B. R. \& F. Bärlocher. 1996. Variable effects of air-drying on leaching losses from tree leaf litter. Hydrobiologia. 325:173-182.

12

Teal, J. M. 1962. Energy flow in the salt marsh ecosystem of Georgia. Ecology. 43:614-624.

14

Tukey, H. B. 1970. The leaching of substances from plants. Annual Review of Plant Physiology. $16 \quad 21: 305-324$.

18 Webster, J.R. \& E.F. Benfield. 1986. Vascular plant breakdown in freshwater ecosystems. Annual Review of Ecology and Systematics 17: 567-594 
2 Table 1: Physical location, description of collection sites, the ratio of oven-dried mass to air-dried mass ( \pm stdev) for each species, and the date (month/year) of each collection and experiment. Site identifiers in parentheses refer to exact locations of FCE-LTER

4 and North Inlet NERR sampling stations.

\begin{tabular}{|c|c|c|c|c|c|c|}
\hline Site & $\begin{array}{c}\text { Lat/Long } \\
\text { (decimal degrees) }\end{array}$ & Wetland type & $\begin{array}{c}\text { Fertility / } \\
\text { Nutrient status }\end{array}$ & $\begin{array}{l}\text { Species } \\
\text { collected }\end{array}$ & $\begin{array}{c}\text { Oven:Air mass } \\
\text { (stdev) }\end{array}$ & $\begin{array}{c}\text { Collection } \\
\text { Date }\end{array}$ \\
\hline $\begin{array}{l}\text { SE Everglades, FL } \\
(\mathrm{TS} / \mathrm{Ph} 4)\end{array}$ & $25.315 \mathrm{~N} /-80.522 \mathrm{~W}$ & FW slough & $\begin{array}{c}\text { oligotrophic, } \mathrm{P}- \\
\text { limited }\end{array}$ & $\begin{array}{c}\text { Cladium } \\
\text { jamaicense }\end{array}$ & $\begin{array}{c}0.879 \\
( \pm 0.007)\end{array}$ & Mar. 2001 \\
\hline $\begin{array}{l}\text { SE Everglades, FL } \\
(\mathrm{TS} / \mathrm{Ph} 5)\end{array}$ & $25.295 \mathrm{~N} /-80.520 \mathrm{~W}$ & FW marsh & $\begin{array}{c}\text { oligotrophic, P- } \\
\text { limited }\end{array}$ & $\begin{array}{c}\text { Eleocharis } \\
\text { spp. }\end{array}$ & $\begin{array}{c}0.795 \\
( \pm 0.006)\end{array}$ & Apr. 2001 \\
\hline $\begin{array}{l}\text { Taylor River, FL } \\
\text { (TS/Ph 7b) }\end{array}$ & $25.197 \mathrm{~N} /-80.642 \mathrm{~W}$ & mangrove & $\begin{array}{c}\text { oligotrophic, } \mathrm{P}- \\
\text { limited }\end{array}$ & $\begin{array}{c}\text { Rhizophora } \\
\text { mangle }\end{array}$ & $\begin{array}{c}0.354 \\
( \pm 0.019)\end{array}$ & Aug. 2000 \\
\hline $\begin{array}{l}\text { Clambank Creek, } \\
\text { SC (North Inlet, CB) }\end{array}$ & $33.334 \mathrm{~N} /-79.193 \mathrm{~W}$ & salt marsh & $\begin{array}{c}\text { oligotrophic, } \mathrm{N}- \\
\text { limited }\end{array}$ & $\begin{array}{c}\text { Spartina } \\
\text { alterniflora }\end{array}$ & $\begin{array}{r}0.842 \\
( \pm 0.004)\end{array}$ & Jul. 2002 \\
\hline
\end{tabular}

6 
Table 2: Initial concentrations of salinity, TOC, TN, and TP in water sources used for each

2 leaching experiment.

\begin{tabular}{ccccc} 
Experiment (species) & Salinity (\%) & TOC $(\mathbf{m M})$ & TN $(\boldsymbol{\mu M})$ & TP $(\boldsymbol{\mu M})$ \\
\hline C. jamaicense & 0 & 1.16 & 66.95 & 0.33 \\
Eleocharis spp. & 0 & 2.02 & 134.49 & 0.17 \\
$\quad$ R. mangle & 0 & 1.01 & 36.38 & 0.12 \\
S. alterniflora & 15 & 0.22 & 17.24 & 1.59 \\
\hline
\end{tabular}


Table 3: $P$-values from one-factor ANOVAs testing the effect of poison on the release of TOC

2 and TP from each species after 1 day and after 21 days of incubation. In all significant tests $(P<$ 0.05), releases from leaves in poisoned bottles were greater than releases in non-poisoned bottles.

4 'N.S.' indicates no significant difference in the release of a given constituent between poisoned and non-poisoned bottles.

6

\begin{tabular}{lcccc}
\hline Species & 1 Day (TOC) & 21 Days (TOC) & Day 1 (TP) & 21 Days (TP) \\
\hline R. mangle & 0.0060 & N.S. & N.S. & 0.0375 \\
C. jamaicense & 0.0052 & 0.0110 & 0.0129 & 0.0483 \\
Eleocharis spp. & 0.0028 & 0.0014 & 0.0117 & 0.0086 \\
S. alterniflora & 0.0002 & 0.0003 & 0.0010 & N.S. \\
\hline
\end{tabular}


Table 4: Fluxes of nutrients in a representative $1-\mathrm{m}^{2}$ patch of wetland $\left(\mathrm{mol} \mathrm{m}^{-2} \mathrm{yr}^{-1}\right)$ associated

2 with the leaching of fresh detritus from different plant species, estimated from the product of mean leaching fluxes (mol $\left.\mathrm{g} \mathrm{dw}^{-1}\right)$ in this study and litterfall production values $\left(\mathrm{g} \mathrm{m}^{-2} \mathrm{yr}^{-1}\right)$ from

4 the literature. Leaching fluxes to water column are derived from the non-poisoned treatments, leaching fluxes to epiphytic microbes are derived as the difference between poisoned and non-

6 poisoned treatments. Nitrogen fluxes were not measured in poisoned treatments. ${ }^{\text {a }}$ Noe and Childers (in review); ${ }^{\mathrm{b}}$ Rivera-Monroy et al. (in preparation); ${ }^{\mathrm{c}}$ Morris and Haskin (1990).

\begin{tabular}{|c|c|c|c|c|}
\hline Flux & C. jamaicense & Eleocharis spp. & R. mangle & S. alterniflora \\
\hline Litterfall production $(\mathrm{g} \mathrm{dw}$ & $1,789^{\mathrm{a}}$ & $281^{\mathrm{a}}$ & $120^{b}$ & $635^{c}$ \\
\hline $\left.\mathrm{m}^{-2} \mathrm{yr}^{-1}\right)$ & & & & \\
\hline \multicolumn{5}{|c|}{ Leaching flux to water column $\left(\mathrm{mmol} \mathrm{m} \mathrm{m}^{-2} \mathrm{yr}^{-1}\right)$} \\
\hline TOC & 870 & 90 & 4,500 & 610 \\
\hline $\mathrm{P}$ & 0.69 & 0.10 & 0.05 & 6.93 \\
\hline $\mathrm{N}$ & 25 & 4.8 & 1.4 & 7.0 \\
\hline
\end{tabular}

Leaching flux to epiphytic microbes $\left(\mathrm{mmol} \mathrm{m}^{-2} \mathrm{yr}^{-1}\right)$

\begin{tabular}{|c|c|c|c|c|}
\hline TOC & 1,400 & 330 & 1,300 & 1,300 \\
\hline $\mathrm{P}$ & 1.55 & 0.07 & 0.08 & 0.62 \\
\hline
\end{tabular}




\section{List of Figures}

2 Figure 1: Releases of total organic carbon (TOC) from each of four species of leaf material with poison (gray bars) and without poison (white bars) incubated for 1 day (top graph) and for 21

4 days (bottom graph). Error bars represent standard deviations from three replicates. Axis break for bottom graph reveals the disparity in TOC release between $R$. mangle and three macrophyte

6 species after 21 days of immersion in water.

8 Figure 2: Releases of total phosphorus (TP) from each of four species of leaf material with poison (gray bars) and without poison (white bars) incubated for 1 day (top graph) and for 21

10 days (bottom graph). Error bars represent standard deviations from three replicates. Separate yaxis for S. alterniflora is intended to show the magnitude of TP released from a N-limited plant

12 versus that of three P-limited, Everglades plant species after 1 and 21 days of immersion in water.

14

Figure 3: Releases of total nitrogen (TN) from each of four species of leaf material immersed in 16 water without poison for 1 day (white bars) and 21 days (shaded bars). Error bars represent standard deviations from three replicates.

Figure 4: Scatter plot showing how TN:TP molar ratios in incubation water changed through

20 time as a result of leaching and microbial activity associated with the early decay of all four macrophyte species. Data are from non-poisoned treatments only and error bars represent

22 standard deviation of three replicates collected at each sampling interval. 

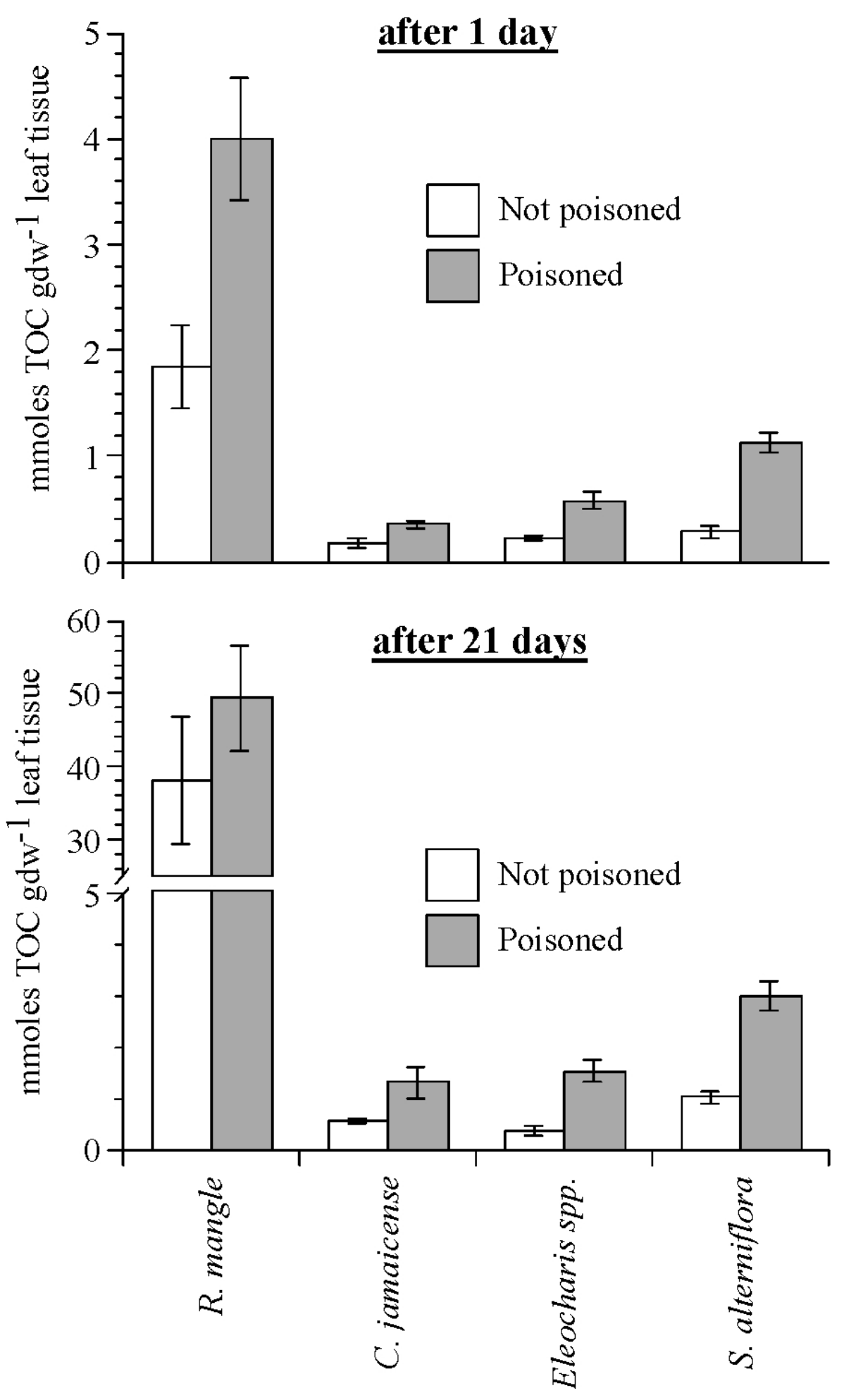

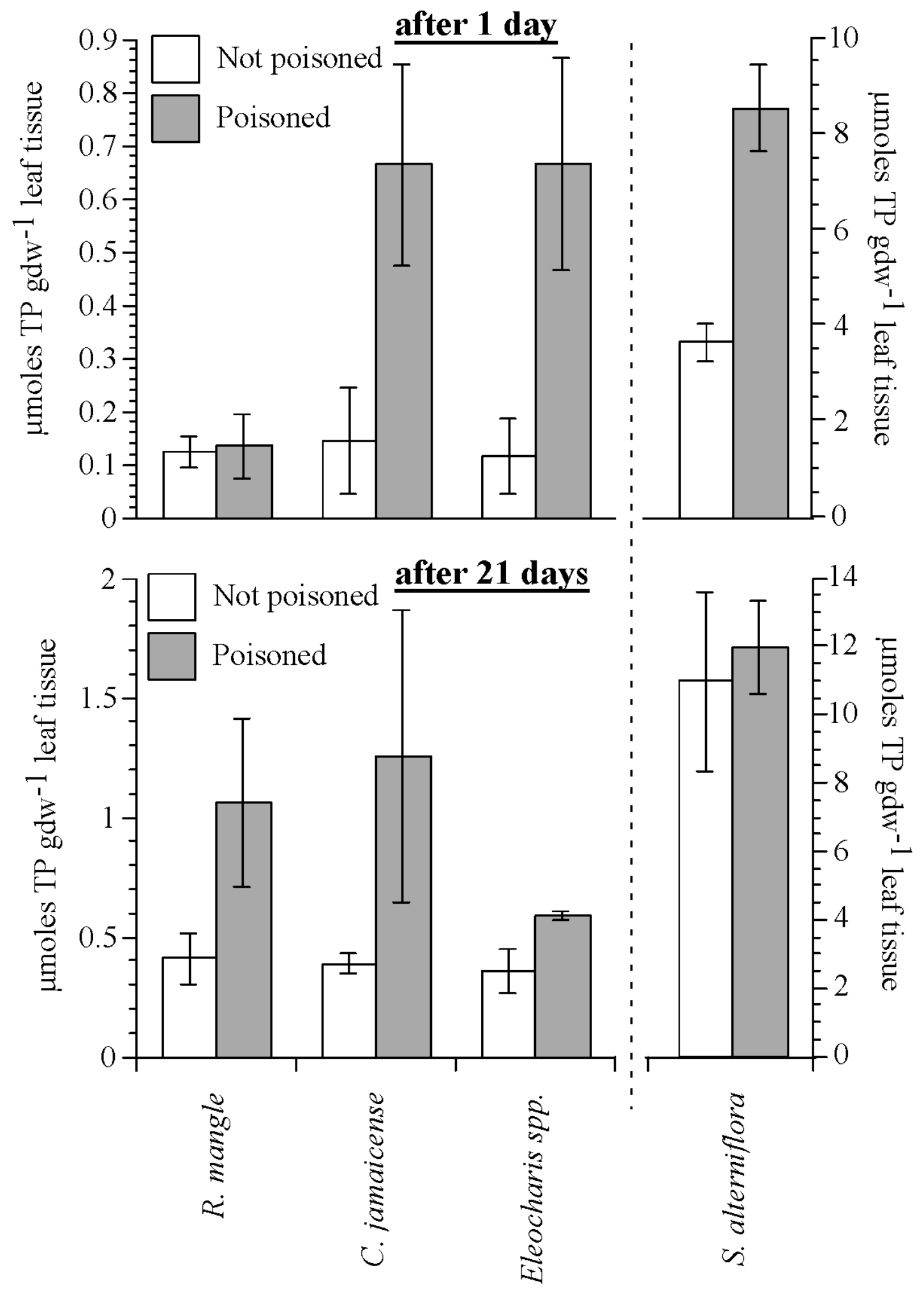


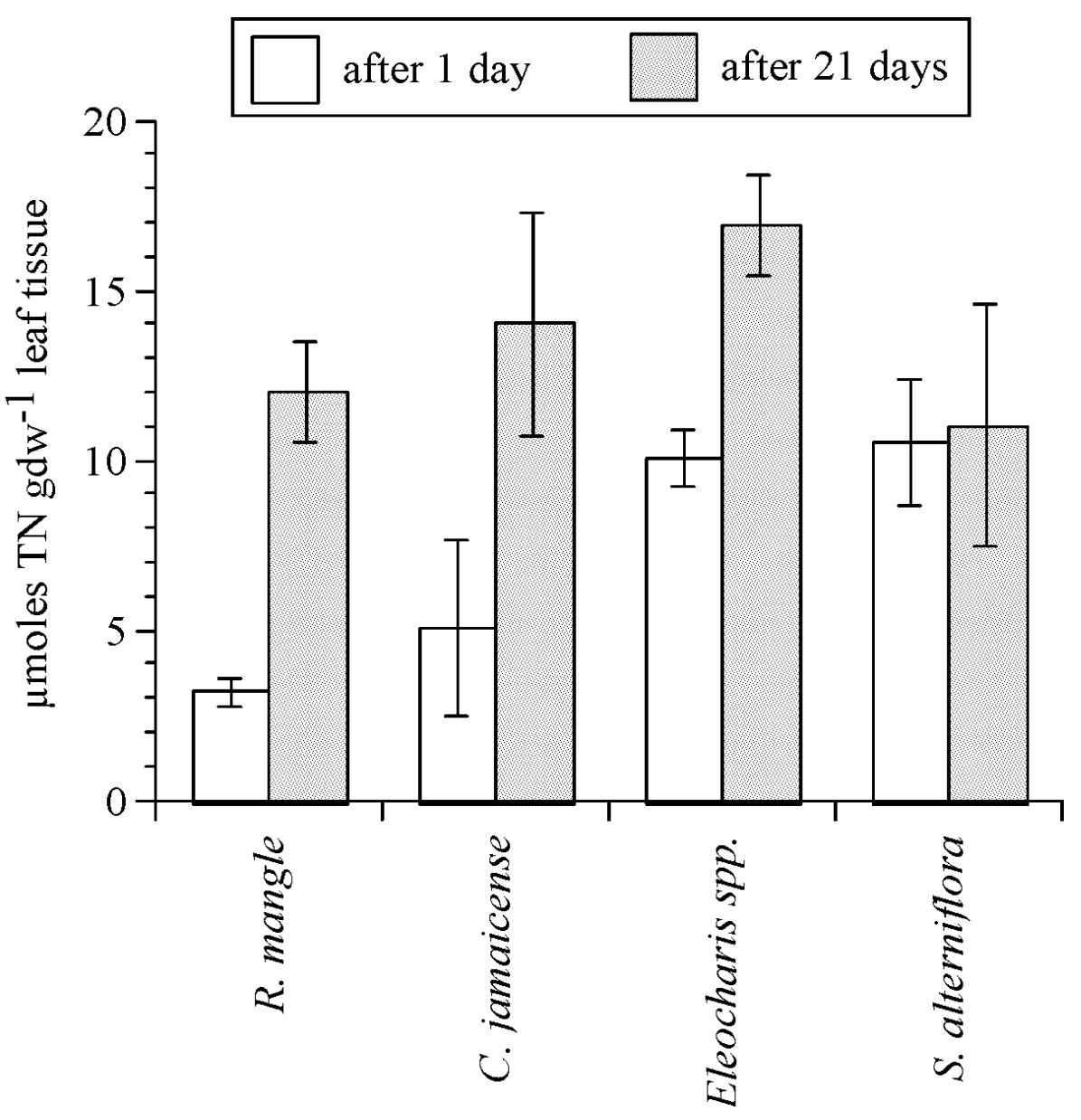



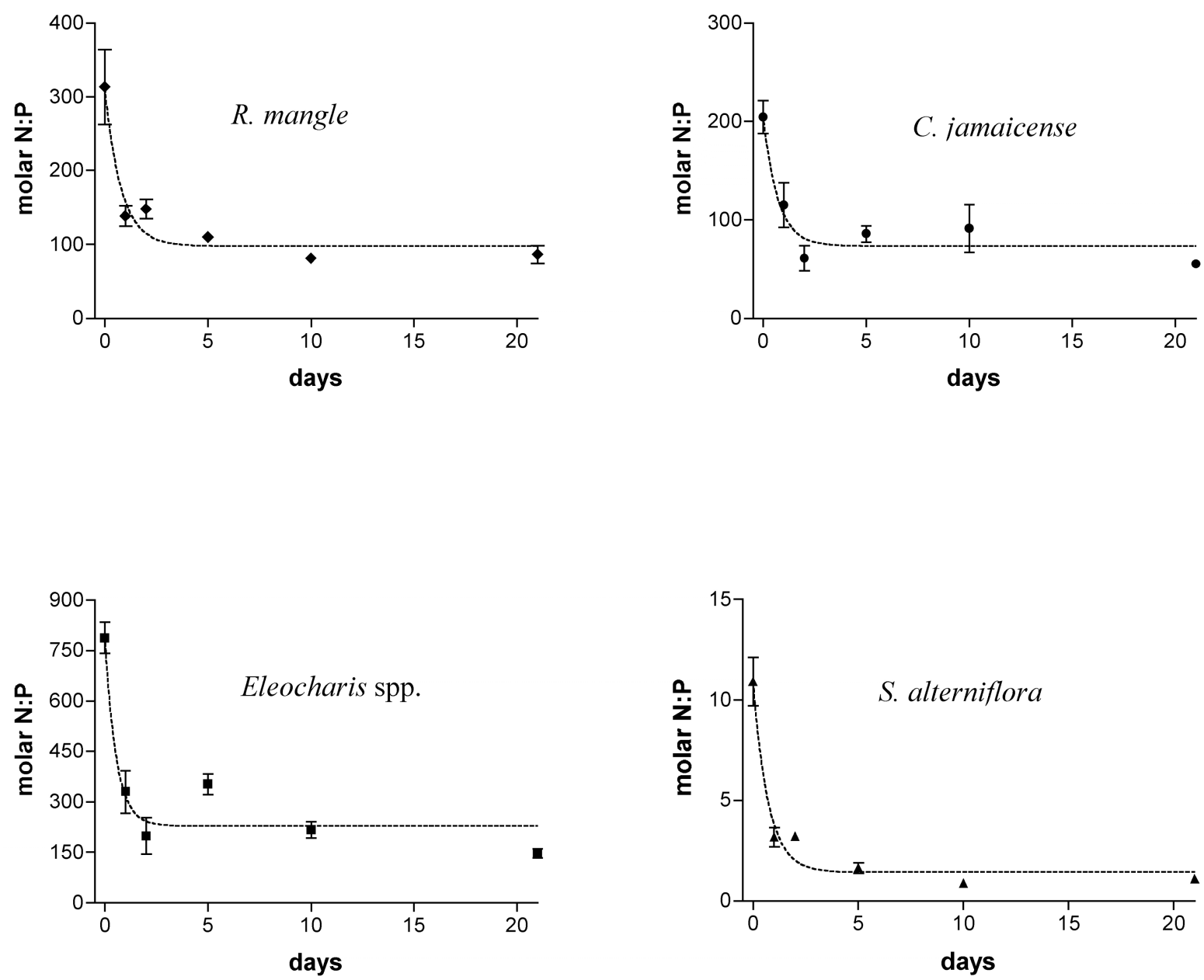